\title{
PERANAN PEJABAT PEMBUAT AKTA IKRAR WAKAF DALAM MENCEGAH TERJADINYA SENGKETA TANAH WAKAF
}

\author{
Oleh. Zahran $\mathbf{R}^{1}$; Hardianti Yusuf. $^{2}$ \\ ${ }^{1}$ IAIN Bone, Indonesia; ${ }^{2}$ IAIN Palopo, Indonesia \\ Email: zahranrafid@gmail.com; hardianti.yusuf@gmail.com
}

\section{Article history:}

Received: $05-08-2020$

Revised: $12-08-2020$

Accepted: $17-08-2020$

\section{Abstract}

This study discusses the role of officials maker of the waqf pledge deed to prevent the occurrence of waqf land disputes, which occurred in the Tanete Riattang Barat District Area. This research uses mixed methods, namely library research and field research. Data was collected through direct interviews with informants PPAIW, namely the Head of Religious Affairs Office (KUA) and the public who were aware of the waqf land dispute in the Tanete Riattang Barat District Area.

The results showed the role of PPAIW in preventing the occurrence of waqf land disputes was very important. Therefore, PPAIW was tasked to make the waqf pledge deed and the waqf land certificate. With the deed and certificate, it would narrow the chances of a waqf land dispute. Besides making endowment pledges and endowment land certificates, the next step was to bring the two disputing parties together and provide an understanding of the disputed waqf land and show the evidence that had been made by PPAIW itself.

Keywords : Certificate Waqf; Deed Pledge of Waqf; Officials Maker of the
Waqf Pledge Deed (PPAIW).

\section{Abstrak}

Penelitian ini membahas tentang peranan Pejabat Pembuat Akta Ikrar Wakaf dalam mencegah terjadinya sengketa tanah wakaf, yang terjadi di wilayah Kecamatan Tanete Riattang Barat. Penelitian ini menggunakan metode campuran, yaitu kepustakaan dan studi lapangan. Data dikumpulkan melalui wawancara dengan informan secara langsung yakni PPAIW (pejabat pembuat akta ikrar wakaf) dalam hal ini Kepala Kantor Urusan Agama (KUA) dan masyarakat yang mengetahui tentang sengketa tanah wakaf yang ada di wilayah Kecamatan Tanete Riattang Barat.

Hasil penelitian menunjukkan peranan PPAIW dalam mencegah terjadinya sengketa tanah wakaf itu sangat penting. Oleh karena, PPAIW yang bertugas membuatkan Akta Ikrar Wakaf dan sertfikat tanah wakaf. Dengan akta dan sertifikat tersebut, maka akan mempersempit peluang terjadinya sengketa tanah wakaf. Selain membuat akta ikrar wakaf dan sertifikat tanah wakaf. Langkah berikutnya adalah mempertemukan kedua belah pihak yang bersengketa dan memberikan pemahaman mengenai tanah wakaf yang menjadi sengketa serta menunjukkan bukti-bukti yang telah dibuat oleh PPAIW itu sendiri.

Kata kunci : Akta Ikrar Wakaf; Sertifikat; Pejabat Pembuat Tanah Ikrar Wakaf (PPAIW). 


\section{A. Pendahuluan}

Tanah sangat penting bagi kehidupan manusia, mencakup aspek sosial, ekonomi, maupun budaya, akan tetapi tanah juga menimbulkan problem hidup bagi manusia, terutama disebabkan karena jumlah penduduk kian bertambah, sedangkan lahan tanah terbatas. Bagi sebagian besar rakyat Indonesia, tanah menempati kedudukan penting bagi kehidupan mereka sehari-hari. ${ }^{1}$ Tanah tidak dapat dipisahkan bagi kehidupan manusia, pada beberapa kelompok masyarakat tertentu, hubungannya dengan tanah sangat erat sehingga dianggap mempunyai nilai yang sangat strategis. Tanah juga digunakan sebagai tempat peribadatan. ${ }^{2}$ Begitu pula berbagai jenis hak yang melekat pada tanah dengan perbedaan prosedur, syarat dan ketentuan untuk memperoleh hak tersebut.

Dalam hukum Islam dikenal banyak cara untuk mendapatkan hak atas tanah, antra lain melalui jual beli, tukar menukar, hibah, hadiah, infak, sedekah, wakaf, wasiat, dan lain-lain. ${ }^{3}$ Menyadari pentingnya kepemilikan tanah di Indonesia, maka Pemerintah bersama DPR-RI telah menetapkan Undang-undang tentang Peraturan Dasar Pokok-Pokok Agraria (UUPA) yaitu UU No. 5 tahun 1960.

Dalam Pasal 14 ayat (1) Undang-Undang Republik Indonesia Nomor 5 Tahun 1960 Tentang Pokok-Pokok Agraria menyebutkan, Dengan mengingat ketentuan-ketentuan dalam Pasal 2 ayat (2) dan (3), Pasal 9 ayat (2) serta pasal 10 ayat (1) dan (2) pemerintah dalam rangka sosialisme Indonesia, membuat suatu rencana umum mengenai persediaan peruntukan dan penggunaan bumi, air dan ruang angkasa serta kekayaan alam yang terkandung di dalamnya: Untuk keperluan negara; Untuk keperluan peribadatan dan keperluan suci lainnya sesuai dengan dasar Ketuhanan Yang Maha Esa; Untuk keperluan pusat-pusat kehidupan masyarakat, sosial, kebudayaan, kesejahtraan dan lain-lain. ${ }^{4}$

${ }_{1}^{1}$ Adijani Al-Alabij, Perwakafan Tanah di Indonesia (Jakarta: Rajawali Pers, 2004), h.1.

${ }^{2}$ Mandzir Qahaf, Manajemen Wakaf Produktif (Jakarta Timur: Khalifa, 2005), h. 3.

${ }^{3}$ Adijani Al-Alabij, Perwakafan Tanab di Indonesia..., h. 4. 2008), h. 562.

${ }^{4}$ R.Soesilo dan Pramudji, Kitab Undang-Undang Hukum Perdata (Cet I, Rhedbook Publisher, 
Pada rumusan pasal tersebut sebelumnya, terkandung makna adanya perintah kepada pemerintah pusat dan pemerintah daerah untuk membuat skala prioritas penyediaan, peruntukan dan penggunan bumi, air, dan ruang angkasa dalam bentuk peraturan yang dibuat oleh pemerintah pusat maupun pemerintah daerah, termasuk pengaturan tentang penggunaan tanah untuk keperluan peribadatan dan keperluan suci lainnya.

Namun demikian, problematika pertanahan terus mencuat dalam dinamika kehidupan bangsa kita dan beberapa daerah di Nusantara, masing-masing memiliki karakteristik permasalahan pertanahan yang berbeda. Keadaan ini semakin nyata sebagai konsekuensi dari dasar pemahaman dan pandangan manusia terhadap tanah. ${ }^{5}$ Persoalan yang banyak dijumpai pada masyarakat, adalah sengketa tanah, dan salah satu jenis sengketa tersebut adalah sengketa tanah wakaf.

Umumnya wakaf dimaknai sebagai usaha menghentikan produktifitas pengelolaan harta secara individual, namun manfaatnya diperuntukan bagi kepentingan sosial masyarakat. Wakaf lahir dengan bersamaan lahirnya kehidupan masarakat di bumi ini. Kata wakaf lahir dari bahasa arab yaitu al-waqf, bentuk masdar (kata benda) dari kata wakafa yang berarti menahan, mencegah, menghentikan, dan berdiam di tempat. Pada awalnya, istilah wakaf menggunakan kata al-habs, akan tetapi pada perkembangan kemudian, istilah wakaf lebih populer dibanding dengan istilah al-habs. ${ }^{6}$

Definisi wakaf menurut rumusan Peraturan Pemerintah No.28 Tahun 1977 tentang perwakafan tanah milik adalah, "perbuatan hukum seseorang atau badan hukum yang memisahkan sebagian dari harta kekayaan yang berupa tanah milik dan melembagakannya untuk kepentingan peribadatan atau keperluan umum lainnya sesuai dengan ajaran Islam."7

${ }^{5}$ Arie Sukanti Hutagalung dkk, Kewenangan Pemerintah di bidang Pertanahan (Jakarta: PT. Raja Grafindo Persada, 2008), h. 8. 2007), h. 34.

${ }^{6}$ Asmuni Mth, Seri Tuntunan Praktis Ibadah Wakaf (Yogyakarta: PT. Pustaka Insan Madani,

${ }^{7}$ Adijani Al-Alabij, Perwakafan Tanah Di Indonesia..., h. 26. 
Dengan definisi tersebut, dapat dipahami bahwa wakaf adalah, menahan harta baik secara abadi maupun sementara, untuk dimanfaatkan langsung atau tidak langsung dan diambil manfaat hasilnya secara berulang-ulang untuk kepentingan umum maupun khusus. Jadi wakaf bertujuan untuk meringankan beban sesama, seperti membantu fakir miskin, anak terlantar, dan kaum dhuafa.

Sebagai objek wakaf atau benda yang diwakafkan, merupakan hal yang sangat penting dalam perwakafan, benda yang diwakafkan dapat diambil manfaatnya, untuk jangka panjang dan tidak habis sekali pakai. Hal ini karena sifat wakaf lebih mementingkan benda wakaf tersebut. ${ }^{8}$ Untuk pengelolaan suatu wakaf, maka wewenang diberikan kepada nadzir, Olehnya itu, berfungsi atau tidaknya harta wakaf tergantung pada nadzir wakaf tersebut ${ }^{9}$.

Mengingat nadzir memiliki peranan penting dalam pengelolaan harta wakaf, seperti yang terjadi di wilayah Kecamatan Tanete Riattang Barat, maka sebelum harta wakaf itu dikelola oleh nadzir, harta wakaf harus diikrarkan terlebih dahulu. Dalam fikih Islam tidak banyak dibicarakan perosedur dan tata cara pelaksanaan wakaf secara rinci. Akan tetapi dalam Peraturan Pemerintah No.28 Tahun 1977 dan Peraturan Menteri Agama No. 1 Tahun 1978 diatur petunjuk yang relatif lengkap.

Menurut Pasal 9 ayat (1) Peraturan Pemerintah No. 28 Tahun 1977, bahwa pihak yang hendak mewakafkan tanah diharuskan datang di hadapan Pejabat Pembuat Akta Ikrar Wakaf (PPAIW) untuk melaksanakan ikrar wakaf, dalam hal ini Kepala KUA Kecamatan. Apabila suatu Kecamatan tidak ada kantor KUA-nya maka Kepala Kantor Kementerian Agama menunjuk KUA terdekat sebagai PPAIW di Kecamatan tersebut. ${ }^{10}$ Selanjutnya PPAIW berkewajiban untuk meneliti kehendak calon wakif dan tanah yang hendak diwakafkan, meneliti para nadzir, meneliti para saksi ikrar wakaf, menyaksikan pelaksanaan ikrar wakaf dan selanjutnya PPAIW membuat akta ikrar wakaf . ${ }^{11}$

\footnotetext{
${ }^{8}$ Asmuni Mth, Seri Tuntunan Praktis Ibadah Wakaf..., h. 48.

${ }^{9}$ Asmuni Mth, Seri Tuntunan Praktis Ibadah Wakaf..., h. 66.

${ }^{10}$ Adijani Al-Alabij, Perwakafan Tanab Di Indonesia..., h. 37.

${ }^{11}$ Asmuni Mth, Seri Tuntunan Praktis Ibadab Wakaf..., h. 104.
} 
Apabila dalam perwakafan, seorang wakif, ahli waris atau nadzir telah melanggar perjanjian yang telah dibuatnya seperti yang terjadi di wilayah Kecamatan Tanete Riattang Barat, yaitu wakif ingin menarik kembali harta yang telah diwakafkannya sehingga menimbulkan sengketa antara wakif dan pengelola wakaf (nadzir), maka penyelesaiannya dilakukan oleh pihak yang berwenang dengan yang merasa dirugikan dan diselesaikan dengan cara musyawarah, bila dengan musyawarah tidak berhasil maka upaya terakhir adalah melalui sidang di Pengadilan Agama. Dalam Pasal 12 Peraturan Pemerintah RI Nomor 28 Tahun 1977 tentang perwakafan tanah milik disebutkan bahwa "penyelesaian perselisihan yang menyangkut persoalan perwakafan tanah, disalurkan melalui Pengadilan Agama setempat sesuai dengan ketentuan peraturan perudangundangan yang berlaku. ${ }^{12}$

\section{B. Metode Penelitian}

Penelitian ini merupakan penelitian kualitatif dengan metode campuran kepustakaan dan lapangan. Dengan pendekatan yuridis sosiologis, yaitu menjelaskan masalah yang diteliti dengan hasil penelitian yang diperoleh dalam kaitannya dengan peraturan hukum dengan melihat kehidupan dan kenyataan yang berkembang dalam masyarakat. Penelitian ini deskriptif atau memberi gambaran yang jelas, dan dapat memberikan data tentang obyek yang diteliti. Dalam hal ini untuk menggambarkan peranan PPAIW dalam mencegah terjadinya dan menyelesaikan sengketa wakaf di Kecamatan Tanete Riaattang Barat.

\section{Pembahasan}

\section{Peranan PPAIW Dalam Mencegah Terjadinya Sengketa Tanah Wakaf}

PPAIW (Pejabat Pembuat Akta Ikrar Wakaf) adalah orang yang diberi kewenangan yang ditunjuk oleh Menteri Agama dalam hal ini kepala Kantor Urusan Agama (KUA) untuk mengatur dan menangani masalah perwakafan. ${ }^{13}$

\section{8.}

12 Suparman Usman, Hukum Perwakafan Di Indonesia, (Serang: Darul Ulum Press, 1994), h.

${ }^{13}$ H.Abd Aziz D, Kepala Kua Tanete Riattang Barat,"Wawancara",Watampone Kecamatan Tanete Riattang Barat,Tanggal 13 Agustus 2012. 
PPAIW mempunyai peranan sangat penting untuk mencegah terjadinya sengketa tanah wakaf bagi kehidupan masyarakat di era sekarang ini, khususnya di wilayah Kecamatan Tanete Riattang Barat. Karena tidak menutup kemungkinan orang yang sudah mewakafkan tanahnya. Namun di kemudian hari, akan terjadi sengketa disebabkan oleh berbagai masalah, misalnya wakif sudah meninggal sedangkan bukti-bukti pemberian wakaf tidak ada. Boleh jadi ahli waris yang keberatan dan ingin mengambil kembali harta yang telah diwakafkan oleh wakif atau pewakif berubah pikiran dan ingin menarik kembali tanah yang telah diwakafkannya.

Untuk menghindari dan mencegah agar tidak terjadi sengketa atau masalah di kemudian hari. Maka PPAIW mengajak para wakif, nazhir, dan masyarakat yang ingin mewakafkan tanah, agar datang ke Kantor Urusan Agama (KUA) untuk mendaftarkan tanahnya. Untuk selanjutnya dibuatkan Akta Ikrar Wakaf. Dengan adanya akta ikrar wakaf dan sertifikat tanah wakaf yang dibuat oleh PPAIW maka lebih mudah memperlihatkan dan mendapatkan bukti-bukti jika terjadi sengketa atau hal-hal yang tidak diinginkan di kemudian hari.

Menurut Abd Aziz D, Kepala Kantor Urusan Agama (KUA) atau Pejabat Pembuat Akta Ikrar Wakaf (PPAIW) bahwa sebelum tanah diikrarkan PPAIW lebih dahulu meneliti kehendak calon wakif dan tanah yang hendak diwakafkan dalam hal ini, wakif adalah pemilik penuh atas harta yang diwakafkan, dan dengan kerelaan hati mewakafkan harta bendanya, tanah yang diwakafkan tidak sedang berada dalam sengketa.

Selanjutnya PPAIW meneliti para nazhir dalam hal ini nazhir harus cerdas, kreatif dan profesional, dalam mengelola dan mengembangkan harta benda wakaf. Serta, meneliti para saksi, yang terdiri dari 2 (dua) orang saksi atau lebih. Dan setelah PPAIW meneliti semuanya maka selanjutnya barulah PPAIW menyaksikan pelaksanaan ikrar wakaf dan membuat akta ikrar wakaf. ${ }^{14}$

Setelah wakif mengikrarkan harta benda atau tanah miliknya di hadapan PPAIW (Pejabat Pembuat Akta Ikrar Wakaf) dan di kemudian hari diketahui

${ }^{14}$ H.Abd Aziz D, Kepala Kua Tanete Riattang Barat,"Wawancara",Watampone Kecamatan Tanete Riattang Barat,Tanggal 13 Agustus 2012. 
terjadi sengketa atau muncul masalah yang tidak diinginkan, maka selaku PPAIW yang pernah membuatkan Akta Ikrar Wakaf dan sertifikat tanah wakaf memanggil atau menghadapkan kedua bela pihak yang bersengketa untuk menyelesaikan dan mendamaikan kedua belah pihak yang bersengketa secara kekeluargaan atau musyawarah, dalam hal ini PPAIW menjelaskan dan memberikan pemahaman mengenai perwakafan tanah yang menjadi sengketa itu dan menunjukan buktibukti atau dokumen tertulis yang telah dibuat oleh PPAIW itu sendiri. Dengan adanya bukti-bukti tertulis akan lebih mempermudah PPAIW untuk menyelesaikan sengketa atau masalah yang terjadi.

Apabila wakaf yang menjadi sengketa itu tidak pernah didaftarkan atau dikrarkan di hadapan PPAIW (Pejabat Pembuat Akta Ikrar Wakaf), maka selaku PPAIW (Pejabat Pembuat Akta Ikrar Wakaf) mengajak agar tanah wakaf tersebut segera diikrarkan di hadapan PPAIW (Pejabat Pembuat Akta Ikrar Wakaf) dan memberi penjelasan dan pemahaman kepada pihak yang bersengketa agar mengikrarkan tanahnya dan tidak tejadi sengketa lagi. ${ }^{15}$

Berikut penulis kutipkan hasil wawancara dari pakar wakaf yaitu Andi Sarjan yang pada pokoknya peneliti simpulkan sebagai berikut: Kepala Kantor Urusan Agama (KUA) yang selaku PPAIW (Pejabat Pembuat Akta Ikrar Wakaf) harus mengetahui dan memahami betul perundang-undangan mengenai perwakafan dan fikih wakaf, agar lebih mudah mengetahui permasalahan dan menyelesaikan masalah perwakafan jika terjadi masalah mengenai perwakafan. Dan jika terjadi sengketa mengenai perwakafan maka kasus tersebut menjadi kewenangan Pengadilan Agama jika tidak dapat diselesaikan secara musyawarah. ${ }^{16}$

Jadi menurut penulis, uraian tersebut dapat dipahami bahwa peranan PPAIW dalam mencegah terjadinya sengketa tanah wakaf itu sangat penting PPAIW harus memahami betul undang-undang wakaf dan harusnya tanah wakaf

${ }^{15}$ H.Abd Aziz D, Kepala Kua Tanete Riattang Barat,"Wawancara",Watampone Kecamatan Tanete Riattang Barat,Tanggal 13 Agustus 2012.

${ }^{16}$ Andi Sarjan, Dosen/ Guru Besar STAIN Watampone "Wawancara", Watampone, Tanggal 13 September 2012. 
didaftarkan di Kantor Urusan Agama. Demi kepastian hukum, wakif mengikrarkan tanah wakafnya di hadapan Pejabat Pembuat Akta Ikrar Wakaf (PPAIW) untuk dibuatkan akta ikrar wakaf dan sertifikat tanah wakaf agar ada tanda bukti tertulis bahwa tanah itu telah diwakafkan agar tidak terjadi hal-hal yang tidak diinginkan di kemudian hari.

\section{Langkah-Langkah PPAIW Mencegah dan Menyelesaikan Sengketa} Tanah Wakaf di Wilayah Kec. Tanete Riattang Barat

Mengingat sifat tanah wakaf itu kekal, artinya tidak boleh ada jangka waktu tertentu untuk wakaf. Oleh karena wakaf merupakan amal untuk mendekatkan diri kepada Allah swt. dengan cara mengeluarkan atau menyisihkan sebahagian hartanya di jalan Allah swt. Maka benda (tanah) yang diwakafkan adalah benda yang manfaatnya berlaku secara berkepanjangan seperti tanah. Adapun tanah yang dapat diwakafkan adalah tanah yang mempunyai status hak milik.

Tujuan wakaf yang paling utama adalah mengabadikan harta wakaf agar manfaat atau hasilnya dapat diambil secara terus menerus. Sebagaimana yang pernah dilakukan oleh Khalifah Umar bin Khattab yang mewakafkan hartanya di Khaibar dan hasilnya dimanfaatkan untuk kepentingan keluarga dan kepentingan umum. Untuk menjaga keabadian harta wakaf tersebut diperlukan pembatasanpembatasan yang memungkinkan harta wakaf tersebut tidak mengalami penyusutan atau pengurangan maupun jatuh ke pihak lain, yang dapat mengakibatkan terhentinya tujuan wakaf. Pembatasan tersebut antara lain tidak boleh dijual, dihibahkan atau diwariskan.

Seiring dengan perkembangan zaman, meskipun sudah dilakukan pembatasan sebagai upaya tetap menjaga kekalnya harta wakaf. Tapi pada akhirnya sering terbentur pada kenyataan yang memungkinkan terhentinya amalan wakaf tersebut, seperti yang terjadi di wilayah kecamatan Tanete Riattang Barat.

Menurut Abdul Kahar M, jika wakaf dan zakat dikelola dengan baik maka akan memakmurkan masyarakat yang ada di wilayah ini, contohnya mengelola wakaf produktif seperti mengelola wakaf kebun lalu hasilnya dimanfaatkan untuk kepentingan umat muslim. Namun yang terjadi sekarang ini wakif hanya 
mewakafkan tanahnya untuk kepentingan ibadah seperti mewakafkan tanahnya untuk dibangun masjid dan sarana pendidikan atau mewakafkan tanahnya untuk tanah kuburan. Hal ini terjadi karena kurangnya pemahaman masyarakat tentang wakaf produktif, yang diketahui hanya wakaf konsumtif (pemanfaatan yang langsung pada harta benda wakaf itu sendiri). ${ }^{17}$

Meskipun tanah yang diwakafkan itu bersifat komsumtif, telah didaftarkan dan dibuatkan sertifikat oleh PPAIW, tidak menutup kemungkinan tidak akan terjadi hal-hal yang tidak dinginginkan di kemudian hari, seperti kasus yang terjadi di wilayah Kecamatan Tanete Riattang Barat, yang disengketakan adalah tanah wakaf.

Menurut Abdul Kahar M selaku pihak yang mengetahui masalah sengketa menyatakan bahwa, Ada 2 (dua) wakif mewakafkan tanahnya kepada masyarakat yang berlokasi di Kecamatan Tanete Riattang Barat, Kelurahan Macege dengan luas $343 \mathrm{M}^{2}$. Wakif tersebut mewakafkan tanahnya dengan tujuan untuk kepentingan ibadah dan sekarang sudah dibangun sebuah masjid dan ditempati beribadah oleh masyarakat sekitar.

Awalnya 2 (dua) orang wakif, mengikrarkan tanahnya di hadapan PPAIW (Pejabat Pembuat Akata Ikrar Wakaf) untuk dibuatkan Akta Ikrar Wakaf dan sertifikat lalu ditunjuk 1 (nazhir), dengan tujuan untuk dibangun tempat ibadah atau masjid. Seiring berjalannya waktu masjid pun jadi dan ditempati beribadah oleh masyarakat sekitar. Namun salah seorang dari wakif tersebut, berubah pikiran dan ingin mengambil kembali dan membatalkan tanah yang diwakafkannya. Sedang tanah tersebut telah dibangun masjid dan dipakai beribadah oleh masyarakat sekitar. Tapi wakif tetap berada pada pendiriannya yaitu ingin mengambil tanah yang telah diwakafkannya. Wakif pun melaporkan salah seorang dari pengelola wakaf ke polisi dengan alasan penyerobotan.

Oleh karena, ada bukti tertulis atau dokumen yang telah dibuat oleh PPAIW. Maka sebelum diambil alih oleh polisi PPAIW yang menangani

${ }^{17}$ Abdul Kahar M. PNS (Pegawai Negri Sipil),"Wawancara" Watampone Kecamatan Tanete Riattang Barat,'Tanggal 27 Agustus 2012. 
kasusnya, PPAIW mempertemukan kedua bela pihak yang bersengketa dengan maksud mendamaikannya dengan cara musyawarah atau kekeluargaan. Di sini PPAIW memberikan penjelasan dan pemahaman mengenai tanah wakaf itu dan menunjukan semua bukti-bukti tertulis atau dokumen yang pernah dibuatnya dan walhasil pihak yang bersengketa mengerti, dan ingin berdamai, mereka pun berdamai di hadapan PPAIW dan polisi serta mencabut laporannya tehadap nazhir (pengelola wakaf) kepada polisi. Sampai sekarang masjid itu dipakai dan dipergunakan untuk beribadah oleh umat muslim.

Sesuai dengan kasus yang dipaparkan sebelumnya, maka dapat dilihat bahwa langkah-langkah yang dilakukan oleh PPAIW untuk mencegah terjadinya sengketa tanah wakaf adalah membuatkan Akta Ikrar Wakaf dan sertifikat tanah wakaf dan menyimpan semua berkas atau dokumen itu untuk dijadikan bukti jika terjadi sengketa di kemudian hari. Dengan adanya Akta Ikrar Wakaf dan sertifikat yang telah dibuat oleh PPAIW itu sendiri akan lebih melegakan hati wakif dan nazhir karena tanah wakaf yang dikelolanya telah berkekuatan hukum dan dapat lebih mempersempit atau mengurangi peluang terjadinya sengketa karena terdapat bukti kuat, yang dapat dipelihatkan jika terjadi sengketa atau tejadi hal-hal yang tidak diinginkan.

Pembahasan mengenai langkah-langkah PPAIW dalam menyelesaikan sengketa tanah wakaf, penulis hanya menitik-beratkan atau berfokus pada wilayah Kecamatan Tanette Riattang Barat, sesuai dengan kasus yang dipaparkan sebelumnya, yang dilakukan oleh PPAIW untuk mennyelesaikan kasus tersebut. Karena kasus sengketa ini mempunyai sertifikat dan akta ikrar wakaf maka PPIAW menyelesaikan sengketa ini dengan cara musyawarah atau kekeluargaan yaitu PPAIW menghadirkan dan mempertemukan kedua belah pihak yang bersengketa untuk diberi penjelasan dan pemahaman mengenai perwakafan dan memberi penjelasan mengenai pemanfaatan dan pemberdayaan obyek-obyek wakaf dan penjelasan mengenai sengketa yang terjadi itu, menunjukkan buktibukti surat, sertifikat dan alat bukti yang lainnya yang berkekuatan hukum.

Pada kasus ini penyelesaiannya dilakukan dengan terlebih dahulu mendengarkan, mengikuti saran dan penjelasan-penjelasan yang diberikan oleh 
PPAIW, maka akhirnya kasus ini berhasil didamaikan oleh PPAIW dan pihak kepolisian. Apabila pada kasus ini, para pihak bersengketa tetap bersikukuh keras untuk melanjutkan sengketa tersebut maka kasus ini dilimpahkan ke Pengadilan Agama untuk diperoses secara lanjut. PPAIW hanya berwenang sampai mendamaikan kedua belah pihak yang bersengketa secara musyawarah dan kekeluargaan. Jika PPAIW tidak berhasil mendamaikannya maka dilimpahkan ke Pengadilan Agama menurut ketentuan Undang-Undang Nomor 41 tahun 2004 tentang wakaf dan Peraturan Pemerintah No. 28 tahun 1977 tentang perwakafan tanah milik.

Jadi menurut penulis berdasarkan keterangan yang telah dijelaskan sebelumnya, PPAIW sangat berperan dalam mencegah terjadinya sengketa tanah wakaf, yaitu dengan membuatkan Akta Ikrar Wakaf dan sertifikat, sehingga dapat mengurangi peluang terjadinya sengkta dan terjadi hal-hal yang tidak diinginkan. Begitupun jika terjadi sengketa, PPAIW berperan dalam menyelesaikan sengketa tesebut dengan cara kekeluargaan dan musyawarah yaitu mengajak para pihak yang bersengketa untuk berdamai dengan menunjukkan bukti-bukti yang telah dibuat oleh PPAIW itu sendiri. Apabila pihak yang bersengketa itu tidak mempunyai sertifikat tanah wakaf maka PPAIW mengajak pihak yang bersengketa, agar tanah wakafnya itu diikrarkan dan dibuatkan sertifikat tanah wakaf.

\section{Penutup}

Berdasarkan dari hasil penelitian yang telah dibahas sebelumnya, maka penulis berkesimpulan sebagai berikut: Pertama, peranan PPAIW dalam mencegah terjadinya sengketa tanah wakaf sangat penting. Karena PPAIW membuatkan akta ikrar wakaf dan dengan akta itu akan mempersempit peluang terjadinya sengketa tanah wakaf.

Kedua, langkah-langkah PPAIW mencegah terjadinya sengketa tanah wakaf yaitu membuatkan Akta Ikrar Wakaf dan sertifikat tanah wakaf. Dengan akta dan sertifikat ini, dapat mencegah terjadinya sengketa. sedangkan langkahlangkah dalam menyelesaikan sengketa tanah wakaf adalah mempertemukan kedua belah pihak yang bersengketa dan menyelesaikan sengketa tersebut dengan 
cara kekeluargaan dan musyawarah. Dengan mengajak para pihak yang bersengketa untuk berdamai dengan menunjukkan bukti-bukti yang telah dibuat oleh PPAIW itu sendiri. Apabila pihak yang bersengketa itu, tidak mempunyai sertifikat tanah wakaf maka PPAIW memerintahkan pihak yang bersengketa agar tanah wakafnya itu diikrarkan dan dibuatkan sertifikat tanah wakaf. PPAIW berusaha mendamaikan pihak yang bersengketa sebelum kasusnya dilimpahkan kepada pihak pengadilan agama selaku yang berwenang menangani sengketa ini sesuai ketentuan yang diatur dalam undang-undang.

Untuk itu, perlu adanya Akta Ikrar Wakaf dan sertifikat wakaf yang dibuat oleh PPAIW sehingga dapat memberi kejelasan terhadap pihak-pihak yang mewakafkan tanahnya dan tidak ada keraguan jika terjadi sengketa. Serta, perlu adaya sosialisasi mengenai perwakafan tanah wakaf dan dan pencatatanya, begitupun mengenai harta yang bisa diwakafkan dan pemanfaatannya sehingga masyarakat bisa mengetahui dan memahami lebih jelas masalah perwakafan.

\section{DAFTAR PUSTAKA}

Al-Alabij, Adijani. Perwakafan Tanah Di Indonesia. Jakarta: Rajawali Pers, 2004. Arie Sukanti Hutagalung dkk, Kewenangan Pemerintah Dibidang Pertanahan, Jakarta: PT. Raja Grafindo Persada, 2008.

Asmuni Mth, Seri Tuntunan Praktis Ibadah Wakaf. Yogyakarta: PT. Pustaka Insan Madani, 2007.

R.Soesilo dan Pramudji, Kitab Undang-Undang Hukum Perdata. Cet I, Rhedbook Publisher

Soekamto, Soerjono. Pengantar Penelitian Hukum. Cet.I, Jakarta : UI Press, 1988.

Usman, Suparman. Hukum Perwakafan Di Indonesia. Serang: Darul Ulum Press, 1994.

Qahaf, Mandzir. Manajemen Wakaf Produktif. Jakarta Timur: Khalifa, 2005. 